UDC 930(092):94(477)

DOI 10.24919/2519-058x.7.131216

Vitaliy MASNENKO,

Ph D hab. (History), Professor, Head of Ukraine's History Department of Bohdan Khmelnytsky National University at Cherkasy (Ukraine, Cherkasy)

masnenko@ukr.net

\title{
YURIY NEMYRYCH AS AN IDEAL REPRESENTATIVE OF THE SZLACHTA LAYER IN VYACHESLAV LYPYNSKY'S VISION
}

The article revies a historiographical image of Yuriy Nemyrych, - Ukrainian politician, military chief and diplomat, as reconstructed by Vyacheslav Lypynsky. It is clarified, that the researcher's main attention was drawn to the distinctive features of the aforementioned historical figure as a model representative of the Ukrainian nobility.

Key words: Vyacheslav Lipinsky, Yuri Nemirich, historiographical image, Ruthenian szlachta, Cossack state, Arianism.

Віталій МАСНЕНКО, доктор історичних наук, професор, завідувач кафедри історії Украӥни Черкаського національного університету імені Богдана Хмельницького (Україна, Черкаси) masnenko@ukr.net

\section{ЮРІЙ НЕМИРИЧ ЯК ІДЕАЛЬНИЙ РЕПРЕЗЕНТАНТ ШЛЯХЕТСЬКОГО СТАНУ У ВІЗІЇ В'ЯЧЕСЛАВА ЛИПИНСЬКОГО}

У статті розглядається історіографічний образ украӥнського політика, воєначальника та дипломата Юрія Немирича, сконструйований В'ячеславом Липинським. 3'ясовано, щзо основна увага дослідника зосереджувалась на визначальних рисах вказаного історичного діяча як взіриевого представника руської иляхти, яка долучилась до українського державотворення XVII cm. Початкова конфесійна належність Немирича до протестантизму (аріанства) розглядається як своєрідний інтелектуальний місток $і$ дисидентський досвід, які приведуть його до козаччини й активної участі в розбудові украйнської державності. Також особливо наголошується на його європейській орієнтації. Доводиться, щя історіографічний образ Немирича, створений Липинським, мав не лише суто наукове значення, а й неодноразово актуалізувався як зразковий социальний тип для сучасної української політичної ситуачії.

Ключові слова: В'ячеслав Липинський, Юрій Немирич, історіографічний образ, руська шляхта, козачька держава, аріанство.

The statement of the problem. Yuriy Stephanovych Nemyrych $(1612-1659)$, nobleman, military leader, the outstanding Ukrainian politician, humanist, diplomat, inspirer of the project of the Treaty of Hadiache, and the author of several theological treatises, was one of the characters of the Ukrainian history most estimated by V. Lypynsky. Furthermore, this figure was interpreted by the aforementioned historian as an exemplary image of «the true son of the Ukrainian people», a representative of the local magnate layer whose destiny, however, was tragic.

Publications are based on the research provided by the grant support of the State Fund For Fundamental Research (project № 77/42-2018) 
The analysis of the researches. It is surprising, that some authors (e. g., M. Bryck) unjustly reproached Lypynsky for his as if improper illumination of the figure of Yuriy Nemyrych (Bryck, 1974: 13). At the same time, Yu. Tereshchenko - absolutely in his right manner - emphatically underlines the aforementioned researcher's particular attention to the personality of Yuriy Nemyrych, who was a bright representative of a fate-making phenomenon in the Ukrainian history alias the «turn of that time Ukrainian szlachta to the Ukrainian state life». Besides, it is possible to agree with Tereshchenko's thought on Lypynsky's view of the activity of Yuriy Nemyrych' «accord with his civic stand and the movement of the Dnieper's right-bank Ukrainian szlachta to the national identity, initiated in the middle of the XIX century» (Tereshchenko, 2013: 72-76). I. Hyrych also accentuates the fact of Yuriy Nemyrych becoming a real hero for Lypynsky, after all, «the biography of the latter in the best way confirmed Viacheslav Kazymyrovych's theoretical sociological constructions» (Hyrych, 2012: 201). It is important that the thinker expressively enough felt the parallelism between his own self-presentation and the destiny of his hero. In Nemyrych' vital instruction, his position in religious, political, and state-building questions become patent, and it is possible «to see also paraphrases of idea of the father of national conservatism in territorial patriotism - a basis of the political nation which builds national unity not on blood or belief principles, and on bases of patriotism of the earth» (Hyrych, 2012: 204)

The article's purpose consists in the revelation of the specificity of the reflexion of the image of Yuriy Nemyrych as an exemplary representative of the Ruthenian (alias Ukrainian) szlachta, who joined in the Ukrainian state building in the XVII century, in Viacheslav Lypynsky's scientific and publicistic inheritance.

\section{The statement of the basic material.}

Nemyrych is a representative of the szlachta layer.

The attention to this figure has been caused by several circumstances. First of all, by his aristocratic origin, after all, Lypynsky paid enough attention to those representatives of the aforementioned layer who were active figures in the case of Ukrainian state life. Obviously, all that went about a question of a certain ideal image which would be satisfactorily approached to his own self-identification. Therefore, no wonder that he publicly declared the following: «Never I renounced before and I do not renounce now that I belong to the Polish szlachta kin, since the time I have settled in Ukraine. And why should I renounce that at all? To Polish szlachta many Ukrainians belonged, for example, Konashevych-Sahaidachny, Bohdan Khmelnytsky, Stanislav Krychevsky, Ivan Bohun, Yuriy Nemyrych, Bohdan Stetkevych, Ivan Vyhovsky, Mazepa-Koliedynsky, Orlyk, Kalnishevsky... From the culture of Polish szlachta all the Dnieper's left-bank Ukraine's hetman foremen grew up, of which many were of Polish szlachta origin. I thank God that I have in me the blood of those who created the very idea, the very political concepts of our modern Ukraine. Happy I am that I was born from the blood of my ancestors, my instinctive inclination to the Ukrainian case is the struggle for the power over my own land» (Lypynsky, 1995a: XXVIII-XXIX). As can be seen, Nemyrych was seated at the foreground in the original «szlachta pantheon» of the Ukrainian case, which had been designed by the thinker. Therefore, it is no wonder that Nemyrych became a hero of its first Lypynsky's historical studies, namely «The General of artillery in the Ruthenian Princedom (from the archive of the Nemyrychi)» and «The Arian Diet in Kyselyna on Volhynia in May 1638 (on the history of Arianism in Ukraine)», published in «Notes of the SSC (Shevchenko Scientific Society)» of 1909 and 1910.

Furthermore, in the collection of «From The history of Ukraine» of 1912 the researcher examines the texts of judicial acts on the raid on Yuriy Nemyrych' estate and the information 
about his other activities ( $\mathrm{Z}$ dziejouv Ukrainy, 1912). In more details, this case is analysed in later works in the context of intense struggle for free land ownership in the milieu of the direct producers (peasants, Cossacks, petty szlachta members) and magnates who captured new land possession. Lypynsky summarized as follows: "Yuriy Nemyrych, like the majority of that time prosperous szlachta and magnates from the northwest wood Ukrainian lands was besieged with a colonizational fever, that, with the desire to buy the land in the southern steppe Cossack land Ukraine where «milk and honey flew» (Lypynsky, 1991: 195).

Under such circumstances the Kyiv land barrister Yuriy Nemyrych got in 1643 the right to the disputable land possessions on the banks of the rivers Vorskla and Orelia. Furthermore, a considerable amount of other possession came into his ownership in different ways, so that he «could compete already with the other Ukrainian magnates». Moreover, Nemyrych could even take hold of the property which was given by the king to Stanislav Potocky. But the situation had changed in 1646 after Potocky received «commissar authority over registered Cossacks», and Nemyrych, fleeing from the pursuit of the Arians, had to go abroad. In the result of an armed raid Yuriy Nemyrych' estates passed into Stanislav Potocky's possession. It is noteworthy, that petty bourgeoisie took part in that raid (i. e., Cossacks, migrants who went into the Cossack service, etc.), of all the small towns, which earlier belonged to Nemyrych. Lypynsky pays a special attention to this very circumstance, remarking that it was that «element which hated masters and their state servants, which to a very great extent supports each enemy of the present «lord», no matter whether he was an enemy and the hated magnate» (Lypynsky, 1980: 259-261).

The researcher recognised that "Yuriy, as well as all his contemporaries, in everyday life was a person rather restless»». In particular, Yuriy persistently is at war with his relative, cousin Joseph Charles (...) Nemyrych (of the Olevska line), an ardent Catholic of an orthodox sort; the harm that Yuriy had made to him and his father by his raids, Joseph counts in several thousands and mentions in this in his will» (Lypynsky, 2013b: 417).

V. Lypynsky also paid attention to a very characteristic, from his point of view, situation. After Yu. Nemyrych enters the service of the Zaporozhian Host, and arrives to the capital Chyhyryn, «the Hetman hospitably received that desirable visitor, that educated son of Ukraine, but, nevertheless, he did not give him his manors, which he possessed in the territory of the Sich lands near Kremenchuk and Perevolochna» (Lypynsky, 1991: 130). At the same time, as well as many other Zaporozhian Host starshyna (foremen), he awarded with a «treasure» for his service to the state (Lypynsky, 1991: 200).

Also, it is characteristic that the historian repeatedly placed his intended emphasis on the high social status of his hero. So, explaining circumstances of the cooperation of Yuriy Nemyrych and Radziwill, Lypynsky refutes M. Korduba's thought about an allegedly official subordinated character of these relations: «the Ukrainian magnate was equal to the Lithuanian magnate and the two were linked by their overall aims and common interests. Yuriy Nemyrych' later outstanding participation in the Ukrainian state and national life should not give any grounds to modern Ukrainian historians for thinking that Nemyrych could be only somebody's «servant» (Lypynsky, 1991: 262).

Nemyrych as freethinking Arian

Yuriy Nemyrych' Arianism, as well as his favour towards the Cossacks, according to V. Lypynsky's observation, were the main aspects of imperception of his figure by the majority of later szlachta milieu (including the descendants of Nemyrych kin who had converted into Catholicism). His hero's descendants who lived at the break of the XVII and XVIII centuries, the researcher represents already in negative context, as typical representatives 
of the Ruthenian (Ukrainian) szlachta who had lost their state significance: «These newly-baked" Polish «masters», these Nemyrych' descendants (who by then began converting Catholics from their former Orthodoxy and Arianism)..., in order to prove their «Polishness»" and «true szlachta status», become assiduous propagandists of Catholicism and Polishness" (Lypynsky, 2015a: 266).

As expected, the historian only partly concentrated upon the Protestant aspect of his hero's biography (he did that in the majority of his early works), and, mainly, elucidated his state activity. That, in part, can be explained by Lypynsky's general attitude to this religion (eventually, as well as to all confessions which were considered by it not only from the religious point of view, but - and primarily - from the state one). So, he considered that «the departure of Protestants from the Catholic church» had been «the last stage of the struggle of Germanic barbarians with the material culture, which had been won by them, and spiritual and moral culture of Ancient Rome, by which they had got conquered. Having appropriated this culture, the conquerors wished to free themselves from its authority, its spiritual power. As such a liberation movement, Protestantism played a great role in the matter of completing of the national individualization of the German, Scandinavian and Anglo-Saxon nations» (Lypynsky, 1995b: 86). At the same time, he was convinced that liberal, freethinking, individualistic, and ideologically both unclear and dim attributes of Protestantism represent an significant public danger which can be counterbalanced by means of the «unity of the ruling class» or disciplining influence of the «hierarchical and dogmatic Catholic religious culture». This last, in his opinion, was what the «strongly infected with Protestant freethinking Poland» lacked (Lypynsky, 1995b: 87). The appearance of Arianism proper Lypynsky connects with the weakness and lack of authority of the traditional church: «In our history, for an example the so-called new faith can serve (primarily, Arianism), which had been very strong during the time of the decline of Orthodoxy and which perished completely in the time of its revival» (Lypynsky, 1995b: 68). At the same time, he pays attention to the social aspect of this dogma, that «Arianism in our lands was not exclusively «a belief of grandees», that at meetings people of «different conditions and standards» converged and faced each other, like it take place in democratic orthodox brotherhoods» (Lypynsky, 2013a: 440).

The way to the «new confession» of the Cherniakhivsky branch of the Nemyrych kin had been initiated by Yuriy's father, Stepan, who «was the first to have passed into the fashionable then Arianism». Lypynsky specially placed an emphasis on the heredity as an important moment for him at that time: «from his father Yuriy inherited freethinking views, boldness of thought, and also the adherence to European culture» (Lypynsky, 1991: 194).

Futher on, the historian in details described his hero's high educational level which «Yuriy received, at first, in a well-known then in Poland Arian academy in Rakiv, after which he left to Europe to finish his study at the universities in Holland, then in Oxford and Cambridge, and - at last - in Paris» (Lypynsky, 1991: 194). Therefore, by his education level he exceeded his time Ukrainian szlachta. For Lypynsky its European character was very valuable: «Due to his «European» «Arian confession he was connected with the most Europeanized - so to speak in a modern way - «progressive» part of his stratum» (Lypynsky, 1991: 193).

Yuriy Nemyrych' activity as an adherer of Arianism, according to Lypynsky's statement, consisted in spreading of Arianism ideas and higher education in his own country, in maintenance of the Arian communities on the lands in his possession, particularly, in Cherniakhiv, financing of presbyters and preachers, initiating of debates with Jesuits, and supporting of publication of books. A letter to Krzysztof Radziwill, the Grand Hetman of Lithuania and Vilnius 
Voivoda, from the participants of the Diet in Kyselyna (of 28 May, 1638) is a documentary acknowledgement of the weight of Yuriy Nemyrych as a defender of Arian confession. The document was found by V. Lypynsky in the archive of the Chartoryiski and entered by him into scientific circulation. The name of Yuriy Nemyrych begins the list of the signatories of that petition with the request to protect the «neglected» rights of the Arians.

Thus, Nemyrych was an influential enough secular protector of the «socian science», and it was thanks to him, that «the persecuted in the szlachta milieu of Rzeczpospolita Arianism eventually survived»: «They are headed by Yuriy Nemyrych, an ardent defender of his co-believers not only at Seyms, Diets, in courts and tribunals, and, generally, in the public-state life, but also in the hot that time religious polemics, the author of polemic leaflets, «certain writings», written «in contempt» for the dominating faith..., which circulate amidst the reading public of that time so fond of such literature» (Lypynsky, 2013a: 431). Lypynsky also mentioned some theological works written by Yu. Nemyrych.

The researcher also noticed that Nemyrych had come to the Diet in Kyselyna when returning from the Seym in Warsaw, at which he had entered into the acts a protest against anti-Arian decisions of the Seym. His numerous denunciations in «blasphemy» and judicial claims against him from Ultra-catholic szlachta were also mentioned. Eventually, under the pressure of such prosecutions Yuriy Nemyrych had to go abroad in 1646, but already in 1648 he took part in the Warsaw Seym at which he had to defend himself from attacks on his belonging to Arians.

Afterwards, Nemyrych in a manifesto addressing all dissidents of Rzeczpospolita appeals to the union with «the Eastern, that is, Orthodox church. According to Lypynsky, here «his participation in Arian movement comes to an end, and, at the same time, begins a new phase of his direct struggle for the political and national rights of the Ukrainian people, conducted if not in the rows, then in the close consent with the greatest of that time defenders of these rights, namely, the Cossacks» (Lypynsky, 2013a: 432).

So, Yu. Yuriy Nemyrych' Arian belonging was indeed an intellectual bridge and a powerful dissident experience which led him at last to the Cossacks and to an active participation in development of the Ukrainian statehood. In other words, his choice in favour of his native people was not incidental (and, moreover, it did not follow from his adventurous character), but was conditioned by new spiritual impulses which were characteristic for the Protestant environment. Lypynsky very precisely detected this link, asserting that «it is necessary to take into consideration their better European political education which manifested itself in the inspired by Nemyrych Hadiache condition, all these Arian «novelties», i. e., humanitarian mottoes and democratic ideas, were inoculated to the believers by «the new belief» (Lypynsky, 2013a: 441).

Nemyrych' confessional alteration, his conversion into the «pious faith» (Orthodoxy), at Lypynsky's first sight, was of political character - «here the main role had played the motives purely... political (the cancellation and prosecution of Arianism by Rzeczpospolita)» (Lypynsky, 1980: 313). However, later, in his writing «Ukraine at the breakpoint», the historian supplied this act with a wider range of arguments, underlining the new, essentially state connotations: «The unity with the newly arisen Ukrainian state, - as usual, vigorous and thoroughly consequent in his deeds, Yuriy Nemyrych consolidates and manifests with his turn to the ancestral Orthodox faith» (Lypynsky, 1991: 200). In this sense, such Yuriy Nemyrych' step approximate him to the position of Mykhailo/Stanislav Krychevsky (which fact Lypynsky denied in his earlier works). It is interesting, that simultaneously with new char- 
acteristics, Lypynsky also refers to the rumours spread by the enemies of Yuriy Nemyrych: for example, that by means of his conversion in Orthodoxy he wanted to marry Rozanda, a Moldavian hospodarivna and Tymish Khmelnytsky's widow (especially having specified in the notes the real marriage condition of his hero, - that he was married and was the husband of Elizabeth Slupetska).

In Lypynsky's positive judgments on Yuriy Nemyrych' change of confession modern researchers see a wider context, namely, its conformity to his conceptual instructions concerning the place of religion and church in the future Ukrainian state, in which the national-state issue would have a higher priority over the one of confession-church (Hyrych, 2012: 203-204). Furthermore, Yu. Tereshchenko assumes that gaining more social weight by such figures as Nemyrych, a person of wide European outlook, high culture, and erudition, which he put in the service of the Cossack state, testified to the restoration of an ancient Ukrainian tradition of religious tolerance in the confessional policy of B. Khmelnytsky in his last years of being hetman (Tereshchenko, 2013: 80). The aforementioned policy, obviously, went ahead of the time and was a bright acknowledgement of Europeanization of the Ukrainian leading social stratum.

The way to a service for the Ukrainian state

V. Lypynsky paid much attention to the basic landmarks of Yu. Nemyrych' life. Thus, the fact of his being a representative of the interests of a considerable part of his szlachta stratum, that its parts which searched for the most optimum variant of realisation of its state potential, was audibly accentuated.

So, yet before the explosion of Kmelnytsky's struggle, Nemyrych «as a loyal royal subjected takes part in the wars of Volodyslav IV with Moscow and Sweden, at the head of his own two military units, under the leadership of royal hetman S. Koniecpolsky» (Lypynsky, 1991: 195).

The Cossack revolt found Yuriy Nemyrych in Dnieper Ukraine, from where he, as well as others members of non-Cossack szlachta, had to escape in order to save his the life. At the same time, the Cossack revolt and Volodyslav's death activated the reformatory part of szlachta to actions. Lypynsky is convinced that at that time «Yuriy Nemyrych, as well as the majority Ukrainian szlachta, trusts in a possibility of reforms and order change in Rzeczpospolita Polska» (Lypynsky, 1991: 196-197). He was made to arrive to such conclusions by an extreme political activity of our hero concerning the election of the new king which best nominee he saw among the representatives of Semyhorod (Transylvania) princely family of Rakoczi, trying to agitate hetman Bohdan Khmelnysky to his plans. The failure of this action and the election of Jan Kazimir as king (he was the candidate of magnate-szlachta Catholic oligarchy, led to a big disappointment in the environment of dissident szlachta. In particular, they were amazed by the fact that such an extremely adverse royal election took place under the consent of the Cossacks. After the failure Yu. Nemyrych distanced himself from active political activities for a certain time.

Nevertheless, already in March 1649 the nobility Diet in Kyiv land elects Yuriy Nemyrych general leader of the local szlachta guard organised for the suppression of Cossack revolt. Together with a military unit of his voivodeship he took part in a Zboriv campaign against the Cossacks. After the Zboriv agreements he became a consecutive adherent of the policy of compromise which was defended and realized by Adam Kysil. In particular, in 1652 and 1654 he was a constant participant of negotiations with the Zaporozhian Host. His election in June, 1655 as the deputy to Kyiv voivodeship «for the pacification of Ukraine» in order to conclude treatises with Khmelnytsky became his last act of participation in the official political life of Rzeczpospolita». 
But already in November of 1655 Yu. Nemyrych, together with a part of Ukrainian $s z-$ lachta breaks off with Jan Kazimir and swears «for citizenship» to the Swedish king (Lypynsky, 1991: 179, 199). Lypynsky explains this step of his hero by his alleged expectations, «that, maybe, the Swedes could make so wishful rest and order in Ukraine». As these hopes appeared not completely justified, Nemyrych applied great efforts to activate the negotiations between Charles Gustav and Bohdan Khmelnytsky, in which he acted as a productive enough intermediary.

However, already in the beginning of 1657 Yu. Nemyrych arrived at the hetman court in Chyhyryn and began his service for the Ukrainian state. For Lypynsky it was an extremely important sign event as it was a testimony to the end of a difficult and long maturing of the Ukrainian Cossacks who «from the revolted against Rzeczpospolita military-plundering nationless caste has turned into a state-national stratum». In that way the obstacles which separated Ukrainian szlachta from the Cossack Ukraine were destroyed. So, «Yuriy Nemyrych" arrival in Chyhyryn at the beginning of 1657 was not an extraordinary event, but the normal phenomenon which marked the completion of a process of the formation of the State and organic connection of all parts of the Ukrainian nation» (Lypynsky, 1991: 200).

The historian specially underlined that except Yu. Nemyrych himself a considerable quantity of representatives of the szlachta environment, including his brother Stepan Nemyrych, Olexander Chaplych-Shpanovsky, Havryil Hulevych-Voiutynsky, Remigijan Surin, and others entered the service for the hetman.

Eventually, Lypynsky names Yuriy Nemyrych among Bohdan Khmelnytsky's outstanding associates of noble origin, having included him into those belonging to the category of politicians and diplomats. In addition, though, he remarked that his hero only in due course had followed «the majority of the people, whereas thereto he «more that once together with Kysil negotiated with the insurgents in the name of Rzeczpospolita» (Lypynsky, 1980: 61).

The figure of Yuriy Nemyrych was of particular interest for Lypynsky just because he, having entered the service for the Ukrainian state, did not leave his szlachta stratum: «As this our outstanding statesman, who later became a creator of one of our state's acts of the greatest weight, namely, the Korsun' Swedish-Ukrainian Condition, and a codifier and inspirer of the Hadiatske Treaty, was neither an exclusively original idealist, nor a declassed politician-dreamer, and was recognised as a representative of the szlachta stratum who could join and did join in the construction of the Ukrainian State only then when this state was able to provide normal existence for the whole Ukrainian szlachta as a separate class of the nation» (Lypynsky, 1991: 193-194). The political choice of Yuriy Nemyrych was extremely valuable for Lypynsky as an argument on acknowledgement of his own position. As I. Hyrych properly underlined, the historian addressed such a choice also to modern Ukrainians of the Polish culture: «He considered that it was necessary to remain in their social status, but to work no more for the Polish, but for the Ukrainian state. Just so, as Yuriy Nemyrych had done in the middle of the XVII century. Although he remained a big land owner and master, but he transferred into side of the Cossacks. - the force which then created the Ukrainian state» (Hyrych, 2012: 203). Hence, it all went about a real question of a bilateral process of the establishment of the Ukrainian state as a mature political organism and the comprehension by the szlachta of its place in the process of this state building.

Lypynsky focuses attention that the Ukrainian szlachta gave the people in hard times «their knowledge, their mind». Yu. Nemyrych as one of the creators of the Hadiache union, the agreement which guaranteed to Ukraine the extensive rights of «the Great Princedom 
of Ruthenians», and a «rich master, skilled in sciences, who got education in Holland, once a powerful Kyiv land barrister in the foreign for him Rzeczpospolita, may serve a most indicative example of such intellectual service. Then he became an ordinary Cossack colonel among his people» (Lypynsky, 2015b: 191).

After all, V. Lypynsky became interested in Yu. Nemyrych, first of all, as a natural statesman and one of the most active adherents of the Ukrainian state. He invariably sees him within a circle of those, «who with their entire soul trusted and still trust in the «violent thoughts» of hetman Bohdan Khmelnytsky about the free, independent, great and strong Ukrainian State, one of those who struggled for such a state not «under compulsion», but from their will, not because of a momentary wave of propaganda, but by the work of their whole life...» (Lypynsky, 1995a: 41).

The tragedy of the destiny of all the "Nemyrychi».

For Lypynsky Yu. Nemyrych' tragical destruction became a constant nutritious ground for deep considerations and statements, in the majority entirely justified, but at times rather emotionally painted. The researcher was inclined to think that the murder of Yuriy Nemyrych by pro-Moscow minded Cossacks at the moment of his greatest rise as a Ukrainian statesman (during the conclusion the Hadiache union) was not only a casual confluence of adverse circumstances, but testified to intrinsic negative political and social processes of that time. First of all, the most part of the szlachta stratum lost its powerful thereto potential and was searching a self-realisation beyond the Ukrainian political space. Lypynsky expressively outlines this process of denationalisation of Ukrainian szlachta. Besides, this disintegration affected all the rest strata of the national organism. This opinion concerns it: «Yuriy Nemyrych paid with life a debt to Moloch of national disintegration» (Lypynsky, 2013b: 424).

It is symbolic, that V. Lypynsky dedicated his conceptual political treatise «Letters to the brothers-grain-growers» to «memory of those noble agricultural knights of the XVII century, who... had come to initiate the Cossack revolt of 1648 and tried to give its blind, anarchical and primitive elements the Ukrainian State Idea, but, unable by a republican method of the organisation to coup with the Ukrainian chaos and to become the base of the Ukrainian State, were lost together with it in the revolt...». In these lines Yu. Nemyrych' destiny also is expressively read. More to that, his tragical image was used by Lypynsky for the definition of the szlachta stratum's self-sacrifice for the sake of realisation of the idea of the Ukrainian statehood. He even put forward a certain «caution» before the Ukrainian statesmen, outlining thereby the danger and ingratitude of their future vocation: «Do you, oh miserable, know what waits for you? - the fate of Yuriys Nemyryches who had been tortured to death by the Cossack mob to enjoy Moscow and Warsaw...» (Lypynsky, 1995a: X). Summing up the defeat of the Ukrainian state creation during the revolution of 1917 - 1921, particularly, regarding the support by the «conscious Ukrainians» of that part of the old local ruling stratum which adhered to the Ukrainian political life, Lypynsky calls the latter «Yuriys Nemyryches (in the plural form), who were killed by those for whom they wanted to sacrifice their lives» (Lypynsky, 1926: 544).

In the end of his earthen way, burdened with the conflict with the majority of the hetman's environment, V. Lypynsky took to an emotional enough comparison of his own destiny with destiny of his heroes. In the letter of 10 February, 1930 to D. Doroshenko, one of the few by then his friends, he put some rhetorical questions and in the answers to which he hypocritically testified to his disappointment in the Ukrainian state affair: «Perhaps, the deaths of Krychevsky, Yuriy Nemyrych and others, abandoned or killed by Ukrainians and, 
consequently, blackened by the foreigners as the «non-impartial» fighters for Ukraine, were necessary for reason that all the strong and creative turned off from this mean Ukraine and went to build the might of Russia or Poland, that might of the organisms, which genesis is founded on companionable love, unity, and courage. After Krychevsky and Nemyrych had played involuntarily on this land such a heavy and ungrateful role, the eternal rest would be granted for them, and to all Ukrainians, like to notorious Marko Prokliatyi (Cursed), who had betrayed and abandoned them, a mutual gnawing would be given in the forms of the Ukrainian issue until the end of time» (Lypynsky, 2003: 638). However, an attentive perusal of even such intentionally aggravated sarcastic maxims can testify to the fact that Lypynsky, actually, enlisted these specified historical figures into the circle of the best representatives of the Ukrainian aristocratic stratum and, accordingly, was assured that their destruction was not in vain. Thereby, his own activity, contrary to adverse circumstances of his destiny, he considered such that assisted the struggle for the Ukrainian statehood.

It is noteworthy, that the study of Yu. Nemyrych was continued by V. Lypynsky's pupils, in particular, Ihor Losky (Losky, 1928: 113-152). According to O. Zadorozhna, this researcher of problems of the Hetmanate in a rather apologetic manner has depictured Yuriy Nemyrych «as a national hero, a statesman and a true European» (Zadorozhna, 2010: 4). It is obvious, that in his researches Losky relied upon the conceptual approaches of his teacher.

The conclusions. Yuriy Nemyrych' figure was used by Lypynsky for outlining of a certain social trajectory of the historical destiny of Ruthenian szlachta in the course of its social transformation, which basic algorithm consisted in the loss of its leading state-building role in Rzeczpospolita. Nevertheless, even in such circumstances the social weight of this stratum was so powerful that its best representatives (no doubt, Yu. Nemyrych among them), found a really possible way-out for the use of their vital energy, namely, to join the Cossacks in the development of the Ukrainian state. That was assisted by the outstanding personal traits of Nemyrych, his erudition and European orientation. Therefore, the historiographic image of Nemyrych, created by Lypynsky, not only had an special scientific value, but also was fully actualized as an exemplary social type for the current Ukrainian political situation. With a great probability, it is possible even to assume that for Viacheslav Lypynsky Yuriy Nemyrych was his original historical Alter ego.

\section{BIBLIOGRAPHY}

Z dziejów Ukrainy, 1912 - Z dziejów Ukrainy: księga pamiątkowa ku czci Włodzimierza Antonowicza, Paulina Święcickiego i Tadeusza Rylskiego / Wydana staraniem dra Józefa Jurkiewicza, Franciszki Wolskiej, Ludwika Siedleckiego i Wacława Lipińskiego; pod red. Wacława Lipińskiego. Kijów, 1912. $675 \mathrm{~s}$.

Брик, 1974 - Брик М. Юрій Немирич на тлі історії України. Лоссер, 1974. 152 с.

Гирич, 2012 - Гирич I. Новий герой української історичної романістики, або Повернення до заповітів В'ячеслава Липинського [Післямова] // Корсак І. Немиричів ключ: роман. К.: Ярославів Вал, 2012. С. 200-206.

Задорожна, 2010 - Задорожна О. Ф. Рід Немиричів у шляхетській корпорації Київського воєводства: майновий статус і політична діяльність (XVI - середина XVII ст.): Авторефер. дис. к. i. н. К., 2010. 21 c.

Липинський, 2013a - Липинський В. Аріянський соймик в Киселині на Волині в маю 1638 р. (Причинок до історії аріанства на Україні) // В'ячеслав Липинський та його доба: Книга третя. Наукове видання / Упоряд. Т. Осташко, Ю. Терещенко. Союз гетьманців-державників; Центр соціогуманітарних досліджень імені В. Липинського; Українська вільна академія наук у США. К.: Темпора, 2013. С. 426-441. 
Липинський, 2013b - Липинський В. Генерал артилерії в.кн. Руського (з архіву Немиричів ) // В'ячеслав Липинський та його доба: Книга третя. Наукове видання / Упоряд. Т. Осташко, Ю. Терещенко. Союз гетьманців-державників; Центр соціогуманітарних досліджень імені В. Липинського; Українська вільна академія наук у США. К.: Темпора, 2013. С. 416-325.

Липинський, 2015a - Липинський В. Данило Братковський - суспільний діяч і письменник кінця XVII століття // Його ж. Суспільно-політичні твори (1908 - 1917) / Ред. Р. Пеленський, I. Гирич, О. Проценко. К.: Український письменник, 2015. Т. 1. С. 264-277.

Липинський, 1995a - Липинський В. Листи до братів-хліборобів. Про ідею і організацію українського монархізму // Його ж. Твори. Політологічна секція. К., Філадельфія: Ін-т Східноєвропейських досліджень НАН України; Східноєвропейський дослідний ін-т ім. В. К. Липинського, 1995. Т. 6. Кн. 1.470 с.

Липинський, 2003 - Липинський В. Листи до Д. Дорошенка // Листування В. Липинського / Ред. Я. Пеленський, Р. Залуцький, Х. Пеленська та ін. К.: Смолоскип, 2003. Т. 1. С. 572-648.

Липинський, 1926 - Липинський В. Покликання «варягів», чи організація хліборобів? Кілька уваг з приводу статті Є. Х. Чикаленка «Де вихід?» // Його ж. Листи до братів-хліборобів про організацію українського монархізму. Писані 1919 - 1926 рр. Відень, 1926. С. 471-580.

Липинський, 1995b - Липинський В. Релігія і Церква в історії України. - К. : Вид-во «Рада», $1995.96 \mathrm{c}$.

Липинський, 1991 - Липинський В. Україна на переломі 1657 - 1659. Замітки до історії українського державного будівництва в XVII- ім столітті // Його ж. Твори. Історична секція. Філадельфія: Східноєвропейський дослідний ін-т ім. В.К. Липинського, 1991. Т. 3. 346 с.

Липинський, 1980 - Липинський В. Участь шляхти у великому українському повстанні під проводом гетьмана Богдана Хмельницького // Його ж. Твори. Історична секція. Філадельфія: Східноєвропейський дослідний ін-т ім. В.К. Липинського, 1980. Т. 2. 638 с.

Липинський, $2015 b$ - Липинський В. Шляхта на Україні. Її роль в житті народу українського на тлі його історії // Його ж. Суспільно-політичні твори (1908 - 1917) / Ред. Р. Пеленський, І. Гирич, О. Проценко. К.: Український письменник, 2015. Т. І. С. 129-233.

Лоський, 1928 - Лоський I. Юрий Немирич канцлер великого княжества руского // Поступ. 1928. № 8. С. 113-252.

Терещенко, 2013 - Терещенко Ю. Проблема європеїзації козацької державності в «Україні на переломі» В'ячеслава Липинського // В'ячеслав Липинський та його доба: Книга третя. Наукове видання / Упоряд. Т. Осташко, Ю. Терещенко. Союз гетьманців-державників; Центр соціогуманітарних досліджень імені В. Липинського; Українська вільна академія наук у США. К. : Темпора, 2013. С. 20-87.

\section{REFERENCES}

Z dziejouv Ukrainy, 1912 - Z dziejouv Ukrainy: ksyonzhka pamyatkova k chsti Vlodzimierzha Antonovicha, Paulina Svięcickiego i Tadeusza Rylskiego [From the history of Ukraine: a memorial book in honor of Volodymyr Antonovych, Paulin Swięcicki and Tadei Rylskyi] / Wydana staraniem dra Jozefa Jurkiewicha, Franciszki Wolskiy, Ludwika Siedleckiego i V'iacheslava Lypynskoho; pod red. V'iacheslava Lypynskoho. Kyiv, 1912. 675 p. [in Polish]

Bryck, 1974 - Bryck M., Yuriy Nemyrych na tli istoriy Ukrainy [Yuriy Nemyrych at the background of Ukraine's history]. Loser, 1974. 152 p. [in Ukrainian]

Hyrych, 2012 - Hyrych I. Novyi heroi ukrainskoi istorychnoi romanistyky, abo Povernennia do zapovitiv V'iacheslava Lypynskoho; Pisliamova [A new hero of the Ukrainian historical novel creativity, or the return to Viacheslav Lypynsky's; instructions] // Korsak I. Nemyrychiv kliuch: roman. Kyiv: Yaroslaviv Val, 2012. Pp. 200-206. [in Ukrainian]

Zadorozhna, 2010 - Zadorozhna O. F. Rid Nemyrychiv u shliakhetskii korporatsii Kyivskoho voievodstva: mainovyi status i politychna diialnist (XVI - seredyna XVII st.) [The kin of the Nemyrychi in a szlachta corporations of Kyiv voivodeship: the property status and political activity (the XVI - mid XVII centuries)]: Avtorefer. dys. k. i. n. Kyiv, 2010.21 p. [in Ukrainian]

Lypynsky, 2013a - Lypynsky V. Ariianskyi soimyk v Kyselyni na Volyni v maiu 1638 r. (Prychynok do istorii arianstva na Ukraini) [The Arian Diet at Kyselyna in Volhynia in May 1638 (A contribution 
to the history of Arianism in Ukraine)] // V'iacheslav Lypynsky ta yoho doba: Knyha tretia. Naukove vydannia / Uporiad. T. Ostashko, Yu. Tereshchenko. Coiuz hetmantsiv-derzhavnykiv; Tsentr sotsiohumanitarnykh doslidzhen imeni V. Lypynskoho; Ukrainska vilna akademiia nauk u SShA. Kyiv: Tempora, 2013. Pp. 426-441. [in Ukrainian]

Lypynsky, 2013b - Lypynsky V. Heneral artylerii v.kn. Ruskoho (z arkhivu Nemyrychiv) [The General of artillery of the Grand Principality of Rus' (from the archive of the Nemyrychi)] // V'iacheslav Lypynsky ta yoho doba: Knyha tretia. Naukove vydannia / Uporiad. T. Ostashko, Yu. Tereshchenko. Coiuz hetmantsiv-derzhavnykiv; Tsentr sotsiohumanitarnykh doslidzhen imeni V. Lypynskoho; Ukrainska vilna akademiia nauk u SShA. Kyiv: Tempora, 2013. Pp. 416-325. [in Ukrainian]

Lypynsky, 2015a - Lypynsky V. Danylo Bratkovskyi - suspilnyi diiach i pysmennyk kintsia KhVII stolittia [Danylo Bratkovsky as a public figure and the writer of end of the XVII century] // Yoho zh. Suspilno-politychni tvory (1908 - 1917) [Social-political works (1908 - 1917)] / Red. R. Pelenskyi, I. Hyrych, O. Protsenko. Kyiv: Ukrainskyi pysmennyk, 2015. T.1. Pp. 264-277. [in Ukrainian]

Lypynsky, 1995a - Lypynsky V. Lysty do brativ-khliborobiv. Pro ideiu i orhanizatsiiu ukrainskoho monarkhizmu [Letters to the brothers-grain-growers. On the idea and organisation of Ukrainian monarchism] // Yoho zh. Tvory. Politolohichna sektsiia [Works. The section of politology] Kyiv, Filadelfiia: In-t Skhidnoievropeiskykh doslidzhen NAN Ukrainy; Skhidnoievropeiskyi doslidnyi in-t im. V.K. Lypynskoho, 1995. T. 6. Kn. 1. 470 p. [in Ukrainian]

Lypynsky, 2003 - Lypynsky V. Lysty do D. Doroshenka [Letters to D. Doroshenko] // Lystuvannia V. Lypynskoho / Red. Ya. Pelenskyi, R. Zalutskyi, Kh. Pelenska ta in. Kyiv: Smoloskyp, 2003. T. 1. Pp. 572-648. [in Ukrainian]

Lypynsky, 1926 - Lypynsky V. Poklykannia «variahiv», chy orhanizatsiia khliborobiv? Kilka uvah z pryvodu statti Ye. Kh. Chykalenka «De vykhid?» [The calling of the Varangians, or the organisation of grain-growers? Some remarks on Ye. Kh. Chykalenko's article «Where is the way-out?»] // Yoho zh. Lysty do brativ-khliborobiv pro orhanizatsiiu ukrainskoho monarkhizmu. [Letters to the brothersgrain-growers about the organisation of Ukrainian monarchism] Pysani 1919 - 1926 rr. Viden, 1926. Pp. 471-580. [in Ukrainian]

Lypynsky, 1995b - Lypynsky V. Relihiia i Tserkva v istorii Ukrainy [Religion and Church in the history of Ukraine]. Kyiv: Vyd-vo «Rada», 1995. 96 p. [in Ukrainian]

Lypynsky, 1991 - Lypynsky V. Ukraina na perelomi 1657 - 1659. Zamitky do istorii ukrainskoho derzhavnoho budivnytstva $v$ XVII-im stolitti [Ukraine at the break of $1657-1659$. Notes to the history of the Ukrainian state building in the XVII century] // Lypynsky V. Tvory. Istorychna sektsiia [Works. The section of History]. Filadelfiia: Skhidnoievropeiskyi doslidnyi in-t im. V.K. Lypynskoho, 1991. T. 3.346 p. [in Ukrainian]

Lypynsky, 1980 - Lypynsky V. Uchast shliakhty u velykomu ukrainskomu povstanni pid provodom hetmana Bohdana Khmelnytskoho [The participation of szlachta in the great Ukrainian revolt under the leadership of hetman Bohdan Khmelnytsky] // Lypynsky V. Tvory. Istorychna sektsiia. Filadelfiia: Skhidnoievropeiskyi doslidnyi in-t im. V.K. Lypynskoho, 1980. T. 2. 638 p. [in Ukrainian]

Lypynsky, 2015b - Lypynsky V. Shliakhta na Ukraini. Yii rol v zhytti narodu ukrainskoho na tli yoho istorii [Szlachta in Ukraine. Its role in the life of the people of Ukraine at the background of its history] // Yoho zh. Suspilno-politychni tvory (1908 - 1917) [Political works (1908 - 1917)] / Red. R. Pelenskyi, I. Hyrych, O. Protsenko. Kyiv: Ukrainskyi pysmennyk, 2015. T. I. Pp. 129-233. [in Ukrainian]

Losky, 1928 - Loskyi I. Yuryi Nemyrych kantsler velykoho kniazhestva ruskoho [Yuriy Nemyrych as the chancellor of the Grand Principality of Rus'] // Postup. 1928. №8. Pp. 113-252. [in Ukrainian]

Tereshchenko, 2013 - Tereshchenko Yu. Problema yevropeizatsii kozatskoi derzhavnosti v «Ukraini na perelomi» V'iacheslava Lypynskoho [The problem of Europeanization of the Cossack statehood in «Ukraine at the break» by Viacheslav Lypynsky] // V'iacheslav Lypynsky ta yoho doba: Knyha tretia. Naukove vydannia / Uporiad. T. Ostashko, Yu. Tereshchenko. Coiuz hetmantsiv-derzhavnykiv; Tsentr sotsiohumanitarnykh doslidzhen imeni V. Lypynskoho; Ukrainska vilna akademiia nauk u SShA. Kyiv: Tempora, 2013. Pp. 20-87. [in Ukrainian]

Стаття надійшла до редакиії 8.04.2018 p. 